\title{
Environmental ethics and crime in the water affairs of the Wonderfontein Spruit Catchment, Gauteng, South Africa
}

\author{
ES VAN EEDEN, M LIEFFERINK AND E TEMPELHOFF*
}

\begin{abstract}
This article provides an analysis of the water history regarding the Wonderfontein Spruit Catchment in the former Far West Rand in South Africa. The major scope for discussion is a short analysis of environmental ethics and crime in this area in the past, and how it has affected man and environment as analysed from a $21^{\text {st }}$ Century perspective. The Wonderfontein Spruit Catchment forms part of the present-day Merafong municipal area, formerly Carletonville. Although voices of concern have featured prominently since the 1960s and even earlier, no extraordinary ethical approach towards this environment and its inhabitants is recorded in history. Bibliographic sources of the Wonderfontein Spruit Catchment currently number over 5000 entries. Despite this impressive production resulting from especially research, reports and whistle blowing in the past 55 years, the area was exposed to limited and insufficient ethically inspired actions, that should have had the ingredients to confirm a positive approach by primary role players regarding environmental management.
\end{abstract}

Key words: Ethics; Environmental Crime; Wonderfonteinspruit Catchment; Merafong; Carletonville; Water pollution; Gold mines.

Disciplines involved: History; Hydrology; Journalism; Philosophy; Plant \& Soil Conservation; Geography; Geology; Agronomy; Geoscience.

* Prof. Elize S. van Eeden is a member of staff in the School for Basic Sciences, North-West University. Mariette Liefferink is an environmental activist, resident in Johannesburg. Elise Tempellhoff is an environmental journalist at Beeld newspaper, Johannesburg. 


\section{Introduction}

A consolidated history of the formal environmental heritage process in South Africa is still due. The same applies to the role and impact on the environment of major role players such as the South African government, mining authorities, local governments, environmental activists, environmentalists in non-government positions and research/academic institutions. An undertaking such as this to obtain a balanced perspective from which departures towards future actions and solutions can be made will be huge. Quite a number of focused research activities under the auspices of each of the abovementioned role players are currently in progress. This article intends to exchange and debate specific information regarding environmental ethics and crime in one such focused activity conducted by researchers in the North-West University Research Niche Area for the Cultural dynamics of water.

Although extensively researched from a variety of academic angles and disciplines, the management of water affairs issues in the Wonderfontein Spruit Catchment in Gauteng, South Africa (formerly part of the Carletonville district in the Far West Rand) still remains controversial and of tremendous concern. At the core of all the rumours regarding environmental destruction and pollution are the health threat and the irreversible harm done to water resources and the environmental face as a consequence. To role players still considering the WSC area as an environmentally sustainable option at present and in the future, differences and distrust prevail. If this status quo is further analysed, one gets to the heart of all the "wronggoings" and "wrongdoings" in the WSC, namely the "happy-go-lucky" environmental ethics or "gentleman's agreement" protocol of the day between the government and the gold mines. This state of affairs has resulted in severe environmental crime scenarios. Obviously, the Wonderfontein Spruit Catchment and the wider area are not unique in this regard. Examples of environmental crime areas can be found nationally and environmentally destructive "partners" are found on the international front.

A uniqueness of the Wonderfontein Spruit Catchment area is that it currently is probably the area in South Africa regarded to be the most written about, environmentally in the most destructive state and probably the most dangerous area with its quiescent, tampered underground dolomitic compartments - any day and time able to show the outcomes of its new Michael Jackson-like environmental face: more sinkholes, more deaths, more water pollution and more health-related problems that stretch much wider than just the Wonderfontein Spruit Catchment area. In the discussion that follows, the focus will be on:

- Geological features of the Wonderfontein Spruit Catchment area; 
- Ethics and environmental crime in the Wonderfontein Spruit Catchment;

- Ethical indicators in the constitution before and after 1994;

- History recalls the Wonderfontein Spruit Catchment: Key ethical and environmental beliefs and attitudes of the day;

- Conclusion.

\section{Geological features of the Wonderfontein Spruit Catchment area}

The Far West Rand rock formations mainly belong to the Transvaal System, which can be divided into the Pretoria Series (shale, quartzite and lava); the Dolomitic Series (dolomitic limestone and chart); and Black Reef Series (quartzite and shale). The Black Reef Series forms the northern boundaries of the dolomite, while its southern boundaries are formed by the Pretoria Series. The dolomitic area is more or less the central part of the Far West Rand and stretches from the east to the south-west. It consists of the valley of the Wonderfontein Spruit that also flows from the east in a south-westerly direction. The dolomitic formations are intersected by dolerite dykes that divide the dolomitic area into separate ground water compartments, each with its distinct water table and springs that originate from the dykes. The main stream in the Oberholzer compartment originated from the Bank Eye and had been supplemented by water pumped from the former West Driefontein mine for years. Gold mining activities lowered the water table in some compartments so that some "eyes" had dried up by the mid sixties. Streams in these compartments have been cement-channelled since the 1950s, and some cement-channelling is regarded as being done inefficiently. ${ }^{1}$

\section{Environmental ethics and crime}

Environmental ethics and crime and the Wonderfontein Spruit Catchment scenario

Seventy-five years of gold mining (and eventually also uranium mining) activity in the Wonderfontein Spruit Catchment has resulted

1 Geo-Science Council Archive (GSCA), State Coordinating Technical Committee (SCTC), File 391-450, Document 404, Report, H. Keersmaekers and A.P. Aldridge, "A study of the quality of dolomitic water in the Far West Rand with special reference to the influence of mine drainage on the formation of sinkhole subsidences and underground water quality", p. 5. 
in polluting natural waters with underground dolomitic waters, dewatering, the formation of sinkholes and the allowing of elevated levels of toxic and radioactive heavy metals in the Wonderfontein Spruit since the fifties. This happened despite the availability of more than half a decade's (confidential and public) scientific information that was withheld from the general public, forming part of the human and environmental injustices committed in this area. Urbanisation increased in conjunction with the mines and associated industries until the Wonderfontein Spruit Catchment in the West Wits Line area also became densely populated. Urbanisation continued until, by the 1970s, people were living and working only tens of metres away from mine dumps and slime dams that proved to be radioactive. ${ }^{2}$

The closure of some mines and the non-compliance with laws stipulating a rehabilitation of mines and mine property have worsened the situation. Ground water, which has been rising gradually since some of the mines closed in the Wonderfontein Spruit Catchment area recently, is now issuing again from springs after being dry for almost 40 years. $^{3}$ The difference is that it is not merely water decanting from these springs, but acid mine drainage (AMD) bearing a concoction of highly toxic and radioactive waste materials. ${ }^{4}$ People living in informal settlements in the rural areas adjacent to the mines on the West Rand have to use ground water due to a lack of municipal water. ${ }^{5}$ Several farming communities also use the water for drinking purposes. On farms, the contaminated groundwater is also used to

2 Compare Water Research Commission (WRC), Report No 1214/1/06, H. Coetzee, F. Winde, P.W. Wade, "An assessment of sources, pathways, mechanisms and risks of current and potential future pollution of water and sediments in goldmining areas of the Wonderfontein Catchment", 2006; National Nuclear Regulator, "Technical report, Radiological impacts of the mining activities to the public in the Wonderfontein Spruit Catchment Area" [also known as the Brenk report], July 2007.

3 E.S. Van Eeden, "Die geskiedenis van die Gatsrand vanaf Trekkervestiging 1838 tot dorpsproklamering 1948“. NWU (MA-dissertation,1988); E.S. van Eeden, "Ekonomiese ontwikkeling en die invloed daarvan op Carletonville, 1948-1988: "n Historiese studie", (NWU, Ph.D., 1992).

4 Council for Scientific and Industrial Research (CSIR), Report CSIR/NRE/WR/ ER/2007/ 0097/C, P.J. Hobbs and J.E. Cobbing, "A hydrogeological assessment of acid mine drainage impacts in the West Rand basin, Gauteng Province", August 2007; C.J. Swart, A.R. James, R.J. Kleyweght \& E.J. Stoch, "The future of the dolomitic springs after mine closure on the Far West Rand, Gauteng, RSA", Environmental Geology, 44, 2003, pp.751-770.

5 Compare M. Liefferink, "Corporate Crime in the Wonderfontein Spruit Catchment", International Water History Association (IWHA) Conference, 20-24 April, 2008; E. Tempelhoff "Groep plaas druk op regering oor spruit se water", Beeld, 4 January 2007; "Mense en omgewing stik onder goudwelvaart. Mynmonopolie se grumoeras", Beeld, 2 February 2007, p. 11. 
water livestock and irrigate crops, which eventually can pose serious health hazards to people eating this produce.

With this article, the focus is to provide a social construction in understanding the application of environmental ethics and scientific knowledge of the day by those dominating the economic scene in the WRC. How and why it can be linked to environmental crime is also discussed. First, an understanding of both concepts is provided.

\section{Ethics and environment ${ }^{6}$}

Philosopher Jozef Keulartz regards science as the master of ethics:

Ethics and morality are typically human interventions or devices that could not be derived directly from nature but had to be fought for and protected in the face of natural evolution. ${ }^{7}$

In addition to the general opinion of Keulartz and others ${ }^{8}$ about ethics, it has been stated in many ways that the main cause of our present ecological predicament results from the Christian conviction that man has been granted "dominion" over the earth and may therefore exploit and use nature for his own ends. ${ }^{9}$

In contemporary ecological debates, poles that are hard to reconcile are mostly opposed, and dilemmas that call for solutions are formulated. In this way (often from a historical perspective) conservation and development, or man and nature, or ecology and economics, or ecology and hedonism, or ecology and Christianity are identified as being essentially in opposition. ${ }^{10}$

As in other disciplines, a lack of a proper discussion regarding ethics and example exists and a theology of the environment has not been

6 A special note of thanks to Professor P.G.W. du Plessis of the North-West University for providing some of the sources and insights on eco-ethics, the Christian and the future.

7 J. Keulartz, Struggle for nature: a critique of radical ecology [translated by Rob Kuitenbrouwer], (Routledge, London, 1998). Introductory notes.

8 Also compare L.M. Benton \& J.R. Short, Environmental discourse and practice (Blackwell Publishers, ca 2000), p. 147.

9 P.G.W. du Plessis, Manuscript on "Eco-ethics, the Christian and the future", Potchefstroom University for CHE (currently North-West University), 27 May 1998.

10 Compare T. Roszak, Making of a counter culture (New York, Faber, 1968); T. Roszak, Persoon en planeet (Amsterdam, Meulenhoff, 1980); R. Attfield, The ethics of environmental concern (Oxford, Blackwell, 1983); R. Attfield, Environmental philosophy (Avebury, Aldershot, 1994); J.A. Nash, Loving nature. Ecological integrity and Christian responsibility (Nashville \& Washington, Abingdon Press, 1991). 
developed. ${ }^{11}$ and in so doing shifts the earthly creation to one side? Within Reformational circles, it has been accepted that ethics mainly and in detail deal with man, and that the ethical mode of existence is an exclusive human issue. ${ }^{12}$ For the Enlightenment, science and technology are edified as instruments of power in the hand of man so that progress can take place, and through plans aimed at growth, the environment is used and exploited for the sake of the interests of man and his society. Benton and Short refer to this approach as nature, as "object" becoming a conceptual container ${ }^{13}$ of whatever thinking of the day, which was rarely questioned.

In the last three to four decades, a nature-centred environmental ethic was accentuated more. Philosophers wrote about some environmental ethics before the first Earth Day in 1970. ${ }^{14}$ A strategy for growth and exploitation is being replaced by a strategy for survival and greening. Relationship and not hostility between man and nature is being sought

... that the land is to be loved and respected is an extension of ethics ... The land ethic simply enlarges the boundaries of the community to include soils, waters, plants and animals. ${ }^{15}$

Modern science and technology also operate with the assumption that progress is based on "the mastery and exploitation of nature". ${ }^{16}$ Christianity is also a strong shareholder in the prevailing humancentred approach and the mentality of exploitation towards the environment in scientific and technological circles. ${ }^{17}$

An environmental ethical approach from a purely scientific perspective, briefly defined, is to decide "what" should be preserved, and "how". ${ }^{18}$ Marshall ${ }^{19}$ referred to this method or approach as part of

11 E. Conradie, Rus vir die aarde (Kaapstad, Lux Verbi, 1995), pp. 61-65.

$12 \mathrm{~W}$. Granberg-Michaelson, Worldly spirituality: A call to take care of the earth (New York, Harper \& Row, 1992), p. 3.

13 Compare B Goudswaard, Capitalism and progress (Grand Rapids, Eerdmans, 1979), p. 50; LM Benton and JR Short, Environmental discourse and practice, p. 147.

14 Compare L. White, "The historical roots of our ecological crisis"; A. Leopold, "The land ethic", A sand county almanac (Oxford University Press, UK, 1968), pp. 201226.

15 A. Leopold, "The land ethic", A sand county almanac (Oxford University Press, UK, 1968),p 223.

16 JA Nash, Loving nature. ecological integrity and Christian responsibility (Nashville \& Washington, Abingdon Press, 1991).

17 L White, "The historical roots of our ecological crisis", De Bell, G. ed., The environmental handbook, (New York: Ballantine,1970), pp.18-26; L Wilkinson, "How Christian is the Green Agenda?", Christianity Today, 1993, pp. 17-20.

18 A. Gutmann and D. Thompson (Eds), Ethics and politics. Cases and comments, Fourth Edition (Australia, Thomson Wadsworth, 2006), pp. 261-263.

19 A. Marshall, "Unknown title", Journal of Applied Philosophy , 1993. 
conservation ethics because of the environment's worth in terms of its utility or usefulness (also known as shallow ecology and not deep ecology). Benton $\&$ Short add a truth to this approach by saying:

At its very inception the scientific idea of nature was blatantly political; this new knowledge of nature was part of a political strategy redefining the social, political and religious order. At some point modern society lost sight of this fact. Scientific knowledge has become absolute and authoritative; science has been presented as objective, morally neutral and detached from social concerns...for many years the study of the environment has been dominated by physical scientists or policy analysts. We have often taken for granted that nature is an objective reality rather than in part a social creation... 'environmental crisis' is much a social phenomenon as a physical one.... ${ }^{20}$

\section{Environmental crime}

Research on environmental crime appears to be very limited and can be regarded as a field that has gained more interest from scientists in the past two decades. ${ }^{21}$ A key aspect of environmental crime on which mutual agreement apparently exists is that it boils down to violence because it is also associated with a physical confrontation that may lead to death. ${ }^{22}$ When corporations for example chemically pollute the water in an environment, they are presenting a community with a violent and physical toxic threat that can be a harmful threat to the health and well-being of the community. From a legal perspective, crime by definition simply means that the law is violated. ${ }^{23}$

In environmental crime, the scope of thinking about it may cause disagreements concerning the scope chosen. Furthermore, sufficient data is required to know or to reveal something about an event, something or behaviour. ${ }^{24}$ Burns refers to research of Lynch, Stretesky and McGurrin in 2002, in which they point out that in a study of toxic crimes and crimes of environmental justice it always appears evident that claims fail because of a lack of data as evidence. Therefore, research on corporate crime has been neglected for many

20 L.M. Benton \& J.R. Short, Environmental discourse and practice, pp. 148-149.

21 R.G. Burns and M.J. Lynch, Environmental crime, a sourcebook (LFB Scholarly Publishing LLC, New York, 2004), pp.

22 A definition by Clifford and Edwards, 1998 as quoted by R.G. Burns \& M.J. Lynch, Environmental crime, a sourcebook, pp. 17,.20

23 J.S. Dryzek and D Schlosberg, Debating the earth. The environmental politics reader, Second edition (Oxford University Press, 2005), pp. 1-658.

24 Compare R.G. Burns and M.J. Lynch, Environmental crime. A source book (LFB Scholarly Publishing, New York, 2004), pp. 1-24. 
years because of a lack of data. ${ }^{25}$ The tackling of environmental crime issues related to violence and human health consequences is mainly a 21 st century effort. ${ }^{26}$

Environmental pollution as a crime scenario can take years to emerge because of the length of time involved. For instance, there is a link between the outcome (e.g. cancer) and invisible pollutants. ${ }^{27}$ One may very well add that because of reports on pollution labelled as "secret" or "confidential' in bureaucratic circles, which are not accessible to the public eye that it concerns directly, it indeed can take years to emerge. Usually, ordinary people are not exposed to and are unaware of crime-related actions.

In the past, pollution and the actions of pollutants were recognised as part of having technical problems instead of environmental crimes. ${ }^{28}$ However, to pinpoint exactly what constitutes crime, as it is defined, is viewed by Burns \& Lynch as a new practice and challenging, because not all harms to the environment are recognised as crimes in a legal sense. Identification of incidents, together with media coverage and continued environmentalist efforts, plays a decisive role in the criminalisation of harms against environment. ${ }^{29}$

Criminologists regard contributions of industries to the pollution and poisoning of the environment as the most common form of corporate violence. In 2002 Rosoff, Pontell and Tillman (as quoted in Burns \& Lynch) suggested that much of the poisoned water comes not from illegal hauling of dangerous waste products but from criminal negligence of industries. In the process, governments as major polluters are not to be ignored, because they sometimes cooperate with major industrial corporations. ${ }^{30}$

The following components are involved in environmental crime:

- Environmental legislation.

25 Compare GA Barreto, "Building community: An environmental approach to crime prevention", (Louisiana State University, USA,), January 2002; 2 R.G. Burns and M.J. Lynch, Environmental crime. A source book, pp. 2-3.

26 Compare Rebovich, 2002 as quoted in R.G. Burns \& M.J. Lynch, Environmental crime, a sourcebook, pp. 2-3.

27 Lynch \& Stretesky (2001) as in R.G. Burns and M.J. Lynch, Environmental crime, a sourcebook, p. 2.

28 Compare the voices of Lowe, Ward, Seymour and Clark, who has changed the scenario of thinking along these lines in 1996, as in R.G. Burns and M.J. Lynch, Environmental crime, a sourcebook, pp. 17, 20.

29 A Munster, "Crime, policing and place: Essays in environmental criminology", Journal of Criminal Justice, 21(4), pp. 423-425; R.G. Burns and M.J. Lynch, Environmental crime, a sourcebook, pp. 15-17.

30 See Simon (2000) and Caldicott (1992)]] as quoted in R.G. Burns and M.J. Lynch, Environmental crime, a sourcebook, pp. 18-19. 


\section{- Enforcement.}

- Legitimate disposal alternatives.

It is said that researchers have an important role to play to act as agents in changing a position by using their research to alter the course of history. This requires researchers to move beyond the traditional treatment of the affected community as "subjects" and to view this opportunity as something more than just another publication. ${ }^{31}$ It can also be added that as long as corporate bodies and governments still handle documents regarding the democratic community they serve according to an autocratic ideology, that long it will take to follow a holistic approach to data retrieval and perusal for the sake of all.

An assessment of the application of environmental ethics in the past from a 21 st century ethical perspective remains difficult because it can easily turn out to be extremely biased. The criteria used (depending on whether you relate to a post-modern ethical perspective or for example a Christian perspective of the environment) can also make a difference in the assessment approach. The same applies to a discussion on environmental crime. Ideological, economic, religious, social, and political legitimisations in a specific historical time could have directed man's thinking and approach towards the environment spontaneously and authoritatively. If historically assessed from a 21st century ethical perspective (and from insights gained through first-hand current evidence regarding a degrading environment) the focus actually should be to recall critically the roots behind these legitimisations and not the actual day-to-day "wrongdoings" by whichever political and institutional power in a particular area. In dealing with the historical roots, one will have to re-direct the discussion to a totally different theme in history. Therefore, the best that can be done is to accept the reality that this discussion of past environmental events in the WRC will involve an ethical view that held the focus that:

- truth obtained from scientific knowledge should be accessible to ensure a multi-diverse solution to a problem or an approach;

- what turned out to be inadequacies of the past be corrected in the present and not sometime in future;

- past inadequacies that have deprived people of reasonable wealth and health be properly addressed from a 21 st century ideological

31 See Bullard and Wright, (1993:836) as mentioned in R.G. Burns and M.J. Lynch, Environmental crime, a sourcebook, p. 275. 
perspective. For South Africa, a democratic vision endorses the basic ethical values spelled out above. The country's environmental acts, as revised and adopted from the mid-nineties, reflect these basic ethical values and, based on them, it is possible to identify corporate crime.

\section{Ethical indicators in the Constitution before and after 1994}

After South Africa had become a union in 1910, the consolidation of environmental management through laws only gained momentum from 1967 with the Physical Planning Act, later renamed the Environmental Planning Act (compare Davenport, 1991). ${ }^{32}$ Even before and after 1910, the government financially supported research by experts in disciplines like geology and geography to grasp the potential richness of the country for mining exploration purposes.

Financially strong gold mining groups from the United States of America and Britain steered the exploitation of South Africa's mineral resources to their benefit in the early 20th century (with the prominent General J.C. Smuts in favour of this approach because it complemented his holistic thinking). The South African government seized these opportunities. ${ }^{33}$

Since the Irrigation and Water Conservation Act No. 8 of 1912 came into effect, various attempts by government to manage dolomitic water in the WFC before 1950 were recalled. ${ }^{34}$ The powers of the Ministry of Water Affairs increased in the 1950s when the new Water Act, No. 54 of 1956, stipulated that a mine be required to have a permit to discharge dolomitic groundwater beyond its boundaries. ${ }^{35}$ If this regulation had been enforced strictly, government would no longer have appeared to be placing an absolute premium on economic prosperity. ${ }^{36}$

32 TRH Davenport, South Africa A modern history, Third Edition (McMillan, China, 1991).

33 E.S. van Eeden, "Weaknesses in environmental action in South Africa: A historical glance on the West Rand (Gauteng Province)", International Journal of Water Resources Development, (Final approved copy for publishing in Nov. 2008).

34 C.J.U. Swart, A.R. James, R.J. Kleyweght \& E.J. Stoch, ÒThe future of the dolomitic springs after mine closure on the Far West Rand, Gauteng, RSAÓ, Environmental Geology, 44, 2003, pp. 751-770.

35 E.S. van Eeden, Some human actions in the destruction and construction of culture and nature - the Merafong region as a case study, The Journal for Transdisciplinary Research in Southern Africa, 2(2), December, 2006 pp. 409-430.

36 E.S. van Eeden, "Weaknesses in environmental action in South Africa: A historical glance on the West Rand (Gauteng Province)", International Journal of Water Resources Development, Nov. 2008. 
A typical example of a lack of strict enforcement is found in a discussion in parliament in the seventies regarding the WRC. Complaints by the official opposition, the United Party (UP), about water pollution at the time were not sufficiently addressed by Cas Greyling, the Member of Parliament (MP) for Carletonville. In fact, there appears to have been a rather nonchalant approach at the time towards environmental destruction (at that stage dewatering, sinkholes and water pollution) and its socio-economic consequences. ${ }^{37}$ UP member H.J. van Eck queried the West Rand and Far West Rand environmental status in $1972^{38}$ (freely translated):

...Then I want to discuss the pollution in the mining industry, and point out that approximately 368 mining dumps exist in the Witwatersrand in the Nigel and Randfontein area, of which 95 are sand heaps and 237 silt dams... We also know that they the mining companies] had to artificially fertilise the sterile steep slopes...the rain still wash salts, acids and other chemicals from these mining dumps; they pollute our rivers...

These questions regarding environmental pollution still remain valid in 2008. To use a typical example from recent parliamentary debates on the WRC and water pollution. Mr G.R. Morgan of the Democratic Alliance (DA) asked the Minister of Water Affairs and Forestry (DWAF):

Question: Are there any risks to humans and animals because of contamination in the Wonderfonteinspruit Catchment Area; if not, how did her department reach this conclusion; if so, what are the relevant details?

Reply: The studies undertaken by the various organisations over a period of time concluded that the radioactivity levels in the river water in the area is well within the water quality safety standards. However, there is a concern regarding elevated levels of Uranium and heavy metals in the sediment. The risk of exposure to humans and animals can be increased if the sediments are stirred up and are in suspension during swimming or when cattle are drinking from the river. The most recent comprehensive study that was done by the Water Research Commission, WRC 1214 (2006) concludes that the present status quo will remain as long as the sediment remain "wet" and that, chemically, the water is fit for consumption, which conclusion is supported by the recent Brenk Report (2007) that was commissioned by the NNR.

Unfortunately the Report in question is based on only a few samples taken and the interpretations in the study are seen as premature at this stage. A public health study looking at blood and urine

37 E.S. van Eeden, A.B. de Villiers, H. Strydom \& E.J. Stoch, "Mines, peoples and sink-holes - An analysis of the Carletonville municipal area in South Africa as a case study regarding policies of secrecy", Historia, 47(1), May, 2003.

38 J.C. Greyling, ca 1950-1988. Private collection (NWU-Vaal Triangle Campus). 
samples compared 36 individuals exposed to the "contaminated" Wonderfonteinspruit with 24 individuals exposed to the "clean" Mooi River in 2002 and, in essence, no difference was found in the profiles. The Department has paid serious attention to the concerns raised and, as a result, has consulted widely. There are a number of different views on the subject and all are being evaluated. The conclusion reached is that while there is reason for concern, the 40 year old problem has not produced any conclusive results, or any reason for immediate action. However, in order to conform to the Precautionary Principle, further investigations are in process. ${ }^{39}$

Although not all role players will agree, the response of government in this reply reflects a more inclusive democratic approach. The language of reporting is also used in a carefully articulated way. It accepts some negative findings but clearly underplays some findings based on "insufficient" research and/or positive outcomes of other research as well as further investigations that are in progress. From the historical outline provided further on, one cannot but wonder what new can evolve from more than 42 years of research that has just been taken for granted.

However, this "democratic" approach to environmental governance has been embedded in the Constitution of the Republic of South Africa since 1996 which, amongst others, states that people have environmental rights. These rights include entitlement to an environment that is not harmful to the health or well-being of people as well as a claim to environmental protection for the benefit of present and future generations. Therefore, Government is obliged to protect, promote and uphold the environmental rights of people. These rights are contained in laws that bind the legislature, the executive, the judiciary and all the associated organs of state. ${ }^{40}$

The Constitution of South Africa provides the basis for the country's progressive environmental legislation by guaranteeing South Africans the right to a safe environment. South Africa, in fact, is the first country in the world to have adopted national water legislation that serves as a tool in the transformation of society based on social and environmental justice. In combination, the Water Services Act, 108 of 1997 and several sections of the National Water Act, 36 of 1998

39 Parliamentary report, National Assembly, Question no 261, Publication internal question paper, 5: Mr G.R. Morgan (DA) to ask the Minister of Water Affairs and Forestry, 29 February 2008.

40 Compare A. Turton, H.J. Hattingh, G.A. Maree et al., Governance as a trialogue: Government -Society-Science in transition (Berlin, Springer Verlag, 2007); R.A. Adler, M. Claassen, L. Godfrey, A. Turton, "Water, mining and waste: an historical and economic perspective on conflict management in South Africa", The Economics of Peace and Security Journal, 2(2), 2007, pp. 33-41. 
were designed to achieve the following:

... redress the inequalities of racial and gender discrimination of the past; link water management to economic development and poverty eradication; and ensure the preservation of the ecological resource base for future generations.

With reference to responsibility and liability regarding pollution of water resources and ecological degradation, Section 19 of the National Water Act states:

An owner of land, a person in control of land or a person who occupies or uses the land on which:

Any activity or process is or was performed or undertaken; or any other situation exists which causes, has caused or is likely to cause pollution of a water resource, must take all reasonable measures to prevent any such pollution from occurring, continuing or recurring.

With reference to responsibility and liability, Section 38(2) of the Mineral and Petroleum Resources Development Act, No. 28 of 2002, states:

Notwithstanding the Companies Act or Close Corporations Act, the Directors of a Company or members of a Close Corporation are jointly and severally liable for any unacceptable negative impact on the environment, including damage, degradation or pollution; advertently or inadvertently caused by the company or close corporation which they represent or represented.

Currently several acts and structures reflect a firm (theoretical) regulating arm by government regarding the mining sector ${ }^{41}$ as seen below: ${ }^{42}$

From a historical perspective, the South African government's awareness and involvement in a structured and formal environmental regulation is reasonably young. An advantage as latecomer is that one could learn from others and improve on the efforts of others. However, the proof of efficient water regulation does not lie in a spotless model of environmental laws and regulations but in the practical implementation of regulations. ${ }^{43}$ In turn, efficient regulation by Government is influenced - and relies on - a complex scenario of

41 An interpretation of the newly adopted constitution as above by M. Liefferink, 2008.

42 Compare E. Swart (CEO), Department of Mineral \& Energy, Power Point presentation on "Application processing procedures", 2007.

43 See P.S. Juuti, S. Katho, H.R. Mäki et al., Governance in water sector - comparing development in Kenya, Nepal, South Africa and Finland (Juvenes Print, Tampere, 2007), pp. 187-191. 
aspects, issues and events, for example in water management. ${ }^{44}$

\section{History recalls the Wonderfontein Spruit Catchment: key ethical and environmental beliefs and attitudes of the day}

In the Wonderfontein Spruit Catchment area, farming practices were the dominant activity between 1838 and 1930. Water issues and laws were then confined to ways it should be used to ensure that all users were treated equally. Issues of water pollution were far from anybody's imagination then, even in the period 1930 to 1956, when farmers and the gold mines shared the Wonderfontein Spruit Catchment area. Owing to knowledge and new technology (such as cementation and dewatering), this status changed rapidly. The first scientific reports were made available to government and the mines in 1957 (of which some were already commissioned in 1952) ${ }^{45}$ During this time, environmental exploitation was regulated by means of the 1956 Water Act.

With the support of a group named the Jordaan Commission, the Department of Water Affairs was also investigating the merits of "total" dewatering in the Wonderfontein catchment area. From the beginning, the work of the Jordaan Commission, which eventually comprised more than 10000 pages, showed several weaknesses. For example, all discussions and findings were confidential and private. ${ }^{46}$ This approach was not only typical of the political and economic ideology of the time, ${ }^{47}$ but also exposed the ethical reality of sufficient knowledge the government of the time had about the fragile WFS environment. The majority of South Africans had no access to the

44 Compare A. Turton, H.J. Hattingh, G.A. Maree et al., Governance as a trialogue: Government -Society-Science in transition (Berlin, Springer Verlag, 2007); R.A. Adler, M. Claassen, L. Godfrey, A. Turton, "Water, mining and waste: an historical and economic perspective on conflict management in South Africa", The Economics of Peace and Security Journal, 2(2), 2007, pp. 33-41.

45 Compare Chamber of Mines Research Organisation, M. Mrost, "Report on an investigation into mine effluents“ (conducted by the CSIR), Johannesburg, March 1957, pp.1-54; Anglo American Corporation of South Africa Limited \& General Mining and Finance Corporation Limited, The National Mechanical Engineering Research Institute, Report UCD 628.335:622.793, First report on Flocculation studies of minewaters from West Driefontein G.M. CO., Libanon G.M. CO.; Venterspost G.M. CO., Doornfontein G.M. CO. (Conducted by the National Mechanical Engineering Research Institute of the CSIR), 10 Dec. 1959, pp. 1-20.

46 E.S. van Eeden, "Weaknesses in environmental action in South Africa..., International Journal of Water Resources Development, Nov. 2008.

47 Compare N. Worden, The making of modern South Africa. Conquest, segregation and apartheid (UK, Blackwell, 1994); S. Marks \& S. Trapido (Eds), The politics of Race, Class \& Nationalism in Twentieth Century South Africa (London, Longman Group, 1987). 
environmental reports, ${ }^{48}$ and this made it easier for Government to "manage" regulations as it saw fit or to simply apply them as "gentleman's agreements" regarding the goldmines. The apartheid government of the time used its position and power to work towards "envirobusing" for the sake of its own economic image. ${ }^{49}$

From an environmental perspective, the crucial years for efficient decision making in the WRC, namely the period 1956 to 1966, turned out to be its "sad years". Amongst others, the following events are recalled:

- Dewatering of underground compartments by the gold mines ${ }^{50}$ (committees, associations \& government's voice in action. ${ }^{51}$ Rewatering even an option, but never applied with Blyvooruitzich as the only mine to vote for rewatering);

- Sinkholes \& subsidences occurred (the fatal ones on Blyvooruitzicht mining area even was expected before the loss of life in August 1964); ${ }^{52}$

- Slime dams \& boreholes appeared by the dozens. In 1967, it was estimated that pumping costs for dewatering amounted to over R100 million. ${ }^{53}$ (Research has pointed out a) the harms of slimes as a filling option that pollute natural waters with dolomitic waters; ${ }^{54}$ b) the dangers of soil imbalances in minerals such as strontium and boron and c) the eventual reducing of farming practices/selling \& buying of farms in favour of mining activities; d) the possible effects heavy metal pollution might have on animals and humans if sufficient care is not taken). ${ }^{55}$

48 Interview, E.J. Stoch/E.S. Van Eeden, 16 March 2007 (Prof. Leslie Stoch is an expert in Agronomy, Soil Science and Crop Nutrition and a former inhabitant/ farmer of the Carletonville area).

49 E.S. van Eeden, "Weaknesses in environmental action in South Africa...", International Journal of Water Resources Development, Nov. 2008.

50 GSCA, SCTC, File 391-450, Document 404, Report, H. Keersmaekers and A.P. Aldridge, "A study of the quality of dolomitic water in the Far West Rand with special reference to the influence of mine drainage on the formation of sinkhole subsidences and underground water quality", 1966, pp.1-2.

51 The State Coordinating Technical Council and the Far West Rand Dolomitic Water Association were founded in 1964 with the initiative of the government. See Geoscience Archive (GA), Pretoria, Minutes of the SCTC \& the FWRDWA, 1964-1998.

52 See SCTC minutes and reports, 1964.

53 CGS-Archive, SCTC, File MM50/1/17/4, Disposal of Dolomitic water in Far West Rand, Part II, Letter, Minister of Mines/The President, Chamber of Mines of South Africa, ca 1967-1968

54 GSCA, SCTC, File 37-76, Document 38, Letter, A. Louw (Consulting Engineer GFSA)/JP Kriel (Secretary of The Department of Water Affairs), 25 June 1964, pp. $1-5$.

55 Compare E.S. van Eeden, „Ekonomiese ontwikkeling en die invloed daarvan op Carletonville, 1948-1988..."; GSCA, SCTC \& FWRDWA documents, 1964-1998. 
- On numerous occasions, research has pointed out that the mines are the main polluters. ${ }^{56}$

The concern of using slimes, as mentioned above, needs accentuation. The National Institute for Water Research (NIWR) was approached during these times to provide suggestions based on its research. The acting director of the NIWR and Chief Research Officer, Mr M.R. Henzen, then reported [to the State Coordinating Technical Committee in confidentiality "from future on", as confirmed with members on 13 August 1964] on 10 August 1964:

In South Africa, the coal and gold deposits are intimately associated with the occurrence of iron pyrites which are either finely disseminated throughout ore bodies and the adjacent strata, or appear sporadically as concretions of sulphuric compounds. Exposure of these materials to atmospheric conditions through mining activities, in slimes, sand and rock dumps, results in seepage, run-off and effluents are of a highly acidic nature [The accentuation by the authors] ${ }^{57}$

Henzen then continued his report by saying:

The uncontrolled discharge of these waters into the natural water courses seriously affects the biological life in the streams; imposes an intolerable mineral load on the recipient streams; results in the deposition of heavy loads of ironhydroxide; aggravates the formation of sinkholes, especially in dolomitic areas; and ultimately produces a water highly mineralized, thus imposing a serious limitation on the usefulness of the water...Mining activities inevitably bring about the crushing and pulverization of the pyretic minerals, and the subsequent dumping of crushed materials in sand, rock and slimes dumps. This process of crushing increases the effective exposed surface area of the pyritic [sic] material, which tends to accelerate the processes of sulphuric acid production....The volumes and concentration of sulphuric acid, emanating from existing mine dumps, are of such magnitude that whole river systems are affected, causing $\mathrm{pH}$ values of below 4 in the river beds and sulphate concentrations of over 2000 p.p.m. The interaction of the sulphuritic waters from mine dumps on dolomitic subsurface formations is a subject which is presently [1964] being investigated by the National Institute for Water Research. It may suffice to state that these sulphuritic waters, derived from mine dumps, react with the calcium and magnesium of the dolomite and produce calcium sulphate, magnesium sulphate and carbon dioxide as products of reaction, together with the sulphates of impurities which occur within the dolomites. These impurities

56 E.S. van Eeden, "Weaknesses in environmental action in South Africa...", International Journal of Water Resources Development, Nov. 2008.

57 GSCA, SCTC, File 37-76, Document 44, Minute, 5th Meeting of the SCTC, 10 August 1964, pp. 1-8. 
can either act as catalysts or inhibitors in the reaction processes...It can be assumed that the types of pyretic materials encountered over the whole Witwatersrand area do not vary considerably, and that the erosion of slime dumps will depend, to a great extent on the precautionary measures adopted to combat the effects of erosion. The effective exposed surface area of pyretic materials which differ between rock, sand and slimes dumps necessarily affect the potential acid production of such dumps..."...From the aforegoing it is apparent that the materials from the slimes dumps usually contain relatively high concentrations of sulphuritic minerals, which can give rise to the production of sulphuric acid. The distribution of slimes dump materials over extensive areas for the purpose of filling cracks and subsidences, and the concomitant increase in exposed surface area of pyritic [sic] material, can only cause an increase in the effective production of sulphuric acid and its effects on the pollution of underground water, the dissolution of the dolomite and the creation of solution voids...From the available information it is considered inadvisable, therefore, to fill cracks and subsidences with slimes dump material, unless it is established that the particular material to be used for this purpose contains no sulphuritic material [The accentuation by the authors] ${ }^{58}$

The only conclusion one can reach from a 2008 perspective is to sigh at the reading of this clear report by Henzen regarding possible water pollution. Nobody has done anything since (or any reports that may have resulted from research are still not freely available), so that the slime dams and the use of slimes in the WRC area have currently reached their ultimate capacity, which can be regarded as a time bomb.

A warning regarding the possible effects of exposure of humans to heavy metal in the WRC has also been raised in a meeting that farmers from the Merafong area, the Far West Rand Dolomitic Association (FWRDWA) as well as the mining and government officials (13 people) have attended in 1967. Amongst others, the minute of 3 November states that the use of slimes to fill sinkholes was a possible cause of pollution. In the memorandum by the veterinary surgeon, Dr Jerry Retief (the only one referred to in the minute without initials), attached to this minute, results obtained from the soil, plants, animals ${ }^{59}$ and water were discussed. In a final note in this memorandum, Dr Retief says: ${ }^{60}$

58 GSCA, SCTC, File 37-76, Document 47, Letter, J.P. Kriel (Minister of Water Affairs)/The Consulting Engineer (Blyvooruitzicht Gold Mining Co. Ltd), 20 August 1964, pp. 1-2.

59 Later veterinary-related reports (as used in this article) by E.J. Stoch and S. Joubert also based their later findings on this FWRDWA minutes and memorandum that can be regarded as a milestone meeting regarding the awareness of definite pollution because of mining activities.

60 CGA, FWRDWA, Memorandum Dr Retief, 3 Nov. 1967. 
After discussions with various doctors, the general opinion is that it is possible that people may eventually be affected or may already have been affected in the same way as the animals

Mr Cas Greyling (LP), who chaired this meeting, summarised the outcome thereof as follows: ${ }^{61}$

As a direct result of mining activities many farmers in this area are being forced from their farms and will have to seek livelihood in towns. From the beginning we [the Government] felt that this problem was a domestic one between the mine sand the farmers, and we therefore tried as much as possible to help the mines find a solution. All analyses and expert opinions were handed on to them immediately. Unfortunately we did not experience the same courtesy from the mines...The [West Driefontein] mine knew that the Department of Water Affairs was at this stage [Oct. 1967] engaged in taking samples of mine water, and yet it apparently did not notify the Department of Water Affairs of this drastic change in the quality of the water. Unless we [Government] can obtain more co-operation from the mines, we feel that our problems cannot be settled in a peaceful way. To avoid any unpleasantness we have turned to you, and we hereby give you our assurance that we shall do all in our power to help you to arrive at a solution.

Clearly, Government accused the mines of not complying with a basic ethically accepted "gentleman's agreement". Water statistics available at this point in time, as proof of the pollution, were not accepted as part of the minutes of this meeting. ${ }^{62}$ From a 2008 perspective, no solution has resulted from this meeting since 1967. Ironically, in the seventies Mr Greyling made a note on his WRC files on sinkholes and water affairs, remarking, "God het my geduld en krag gegee" (God gave me the power and patience). ${ }^{63}$ Clearly, too much patience was allowed if the 21 st century ethical norms and the physical outcomes are criteria to measure the past activities in the WRC.

After 42 years of extensive, additional and new research reporting regarding the WRC, the 1956-1966 findings still prevail, but the situation has presently resulted into an environment:

- that is permanently destructed (one major compartment; contaminated underground dolomitic water; permanent pumping costs; extensive expenses to maintain stability in the environment for further exploitation);

61 CGA, FWRDWA, Minute, 3 Nov. 1967.

62 Interview EJ Stoch/ES van Eeden, 17 May 2008.

63 J.C. Greyling private collection, NWU Vaal Triangle Campus, File WRC on Sinkholes and the Dept of Water affairs, ca 1960-1972. 
- where farming is limited to a minor economical role player; the FWRDWA (Mines)owns the land;

- where health concerns become more evident among farming communities and informal settlement groups but, as in the past, "more evidence" was/is required to force authorities to take action;

- where government is still tuning in to the weal and woes of mining companies;

- in which a closure of the State Coordinating Technical Committee on Sinkholes in 1998 became a reality while more sinkholes are expected in future;

- in which rumours of a closure of the Far West Rand Dolomitic Water Association are also raising concern as it may provide many kinds of unique problems of its own if applied. ${ }^{64}$

The successes and failures of institutions like the DWAF Institute for Water Quality Studies (IWQS) and the DWAF Loopspruit Forum still need to be described. DWAF currently is heading the process of finding solutions to cope with the destructive WRC environment via committees and organs like the Team of Experts (TOX) and the Wonderfontein Regulators Steering Committee (WRSC) under the auspices of the newly founded National Regulators Steering Committee. ${ }^{65}$

Other role players in forums like the Parliamentary Portfolio Committee/Parliamentary Monitoring Group, the Department of Environmental affairs and Tourism (DEAT); the Portfolio Committee; the Department of Minerals and Energy; National Nuclear Regulator (NNR) also still have to earn credibility. Some critics argue that there is reason to believe that information at the disposal of these forums is not sufficiently distributed. Once again, the reference to insufficient

64 Conclusions are based on archival research at the CGS-Archive on the SCTC minutes and the FWRDWA minutes; Also compare A. Turton, H.J. Hattingh, G.A. Maree et al., Governance as a trialogue: Government -Society-Science in transition (Berlin, Springer Verlag, 2007); R.A. Adler, M. Claassen, L. Godfrey, A. Turton, "Water, mining and waste: an historical and economic perspective on conflict management in South Africa", The Economics of Peace and Security Journal, 2(2), 2007, pp. 33-41; E-Mail, Federation for a Sustainable Environment (FSE), 20072008; E.S. van Eeden, "Weaknesses in environmental action in South Africa: A historical glance on the West Rand (Gauteng Province)", International Journal of Water Resources Development, Nov. 2008; E. Tempelhoff, "Mynmonopolie se grumoeras", Beeld, 2 Feb. 2007.

65 Interview M. Keet (DWAF)/E.S. van Eeden, 9 May 2008; E-mail, M Liefferink/ES van Eeden, 9 May 2008. 
environmental reporting (ER) was a point of debate. ${ }^{66}$ This laxity can be regarded as an environmental crime if the South African Constitution is indeed taken seriously. ${ }^{67}$

A growing need for proper environmental regulation resulted in the forming of the Enforcement Directorate (also known as the Green Scorpions), which was eventually placed under the management of the DEAT. Their assignment, among others, covered a regulation of the environmental responsibility by local governments with regard to environmental issues related to water and air pollution. Despite four large departments and their respective divisions responsible for various aspects of the environment, the Government's aim of developing a strong regulatory arm is still not fully realised because of a lack of sufficient co-ordination. As a result, there are still unfortunate incidents in which the inability of the Government to regulate the bigger industries as polluters properly is evident. ${ }^{68}$

Interested role players, specifically in the WFS area (who actually contributed to making the local general public aware of environmental problems) are the Potchefstroom Petitioners (PP), the Randfontein Environmental Action Group (REAG), and the Wonderfontein Action Group (WAG). ${ }^{69}$ Nationally and legally acknowledged non-governmental organisations (NGOs) with an indirect WFS focus (mainly active since the nineties) are the Chronicle Group, Green Cross, Groundwork, the Legal Resource Centre (LRC), Pelindaba Working Group, and Earthlife Africa. To make functioning possible, these NGOs rely on governments, industries, organisations and individuals from national and international spheres to support them. An ironical aspect in this regard is that the South African government and the gold mining industry active in the Merafong and broader mining area also financially support some of these organisations that have taken up the challenge in recent years and

66 Compare with the findings of C.G. Mitchell \& N.W. Quinn, "Environmental reporting disclosure in South Africa: A comparative study of the expectations of selected groups of preparers and users", Meditari Accountancy Research, 13(2), 2005, pp.17-33; E. Tempelhoff, "Groep plaas druk op regering oor spruit se water", Beeld, 4 Jan. 2007; "Mense en omgewing stik onder goudwelvaart. Mynmonopolie se grumoeras", Beeld, 2 Feb. 2007, p. 11; E.S. van Eeden \& I. Brink, "Factors that determine the facilitation of stakeholders in environmental management - some philosophical-historical thoughts with the Merafong area as example", Koers, 3, Nov. 2007 (Page numbers not available yet. In process of printing).

67 Compare M. Liefferink, Private collection, 1980-2007.

68 E.S. van Eeden, "Weaknesses in environmental action in South Africa: A historical glance on the West Rand (Gauteng Province)", International Journal of Water Resources Development, (Final approved copy for publishing in Nov. 2008); Compare M. Liefferink, Private collection, 1980-2007.

69 Compare M. Liefferink, Private collection,, 1980-2007. 
months of "whistle blowing" against these financial supporters concerning the environmental destruction in the Wonderfontein Spruit area. WESSA and the LRC, for example, are partially funded by Gold Fields South Africa, and Earthlife Africa is partially funded by the African National Congress (ANC) government. ${ }^{70}$

In addition, from a historical perspective, some environmental actions, specifically steered by the public were apparently not always as highly regarded as those initiated by government or highly respected industries and/or institutions. This perception has a historical tail linked to people in governmental periods where the majority of the public was visible, but not supposed to be heard. ${ }^{71}$ Therefore, local action groups who also contributed in making the public and media more aware of their water and general environmental pollution problem ${ }^{72}$ were the Potchefstroom Petitioners (PP) and later the Randfontein Environmental Action Group (REAG). An umbrella federation focussing on environmental issues was getting some stand from August 2007, although it is still running a solo course because of a lack of infrastructural capacity and funds. ${ }^{73}$ These well-informed groups have, since the turn of the century (and some earlier), used many opportunities for "whistle blowing" through the news media and the disclosure of environmental incidents and infractions to the Human Rights Commission, the Public Protector, the Director-generals of the relevant organs of Government such as the Department of Minerals \& Energy (DME), The Department of Environment and Tourism (DEAT), the Department of Water Affairs and Forestry (DWAF), the National Nuclear Regulator (NNR) as well as the ministries of the relevant organs of Government. ${ }^{74}$

70 M. Liefferink, Private collection, e-mail letter, M. Liefferink/Dr E.J. Stoch, 14 June 2007.

71 M. Liefferink, Private collection, e-mail letter, M. Liefferink/Dr E.J. Stoch, 14 June 2007.

72 Compare IRIN, "Paying the price for mining", http://www.africafiles.org/ article. asp?id=17261, 15 Feb. 2008; M. Liefferink, Private collection, 1980-2007.

73 M. Liefferink, Private collection, e-mail letter, M. Liefferink/Multiple Recipients, 12 September 2007; 21 September 2007.

74 Compare the recent articles of the SAB award-winning environmental journalist (as reported on 12 October 2007 in the Beeld), E. Tempelhoff, "Groep plaas druk op regering oor spruit se water", Beeld, 4 Januarie 2007; E. Tempelhoff, "Mense en omgewing stik onder goudwelvaart. Mynmonopolie se grumoeras", Beeld, 2 Februarie 2007, p. 11; E. Tempelhoff, "Gifspruit", Beeld, 3 Februarie 2007; E. Tempelhoff, "Owerheid erken Spruit is besoedel", Beeld, 8 Februarie 2007; E. Tempelhoff, "Suur mynwater lei tot sinkgate. Vreet aan dolomietkompartemente", Beeld, 24 April 2007; E. Tempelhoff, "Besoedeling: Gif in die water. Mooirivier lankal deur myne besmet," Beeld, 31 Julie 2007; J. Avril, "Lives at risk. State knew about danger for 40 years". Sowetan: 1,4. 24 July 2007; J. Avril, "Report exposes high water contamination". Sowetan, 3 August 2007; J. Avril, "Poisoned by mines". Sowetan, 20 August 2007; Anon., "SA 'Erin' widens toxic water fight. Water too dangerous for farming“, The Citizen, 14 August 2007. 
Therefore, with more concerned or interested parties as role players on the scene, such as NGOs, some moves have been made in the past two years (2006-2007) to force the mining industry and government: i) to be more explicit in their historical role in the eventual outcome of the WFS environment ${ }^{75}$; ii) to be clear on their intentions of how the WFS environment should be remediated; ${ }^{76}$ and iii) to promptly apply the "polluter must pay principle", which has been so neatly constituted. ${ }^{77}$

Although the availability of some scientific knowledge during the past years has instigated public reporting and whistle blowing in the media, the quiet approach of scientists regarding the mines as main environmental polluters and destructors during the past 55 years $^{78}$

75 Compare the recent articles of the SAB award-winning environmental journalist (as reported on 12 October 2007 in the Beeld), E. Tempelhoff, "Groep plaas druk op regering oor spruit se water", Beeld, 4 Januarie 2007; E. Tempelhoff, "Mense en omgewing stik onder goudwelvaart. Mynmonopolie se grumoeras", Beeld, 2 Februarie 2007, p. 11; E. Tempelhoff, "Gifspruit", Beeld, 3 Februarie 2007; E. Tempelhoff, "Owerheid erken Spruit is besoedel", Beeld, 8 Februarie 2007; E. Tempelhoff, "Suur mynwater lei tot sinkgate. Vreet aan dolomietkompartemente", Beeld, 24 April 2007; E. Tempelhoff, "Besoedeling: Gif in die water. Mooirivier lankal deur myne besmet," Beeld, 31 Julie 2007; J. Avril, "Lives at risk. State knew about danger for 40 years". Sowetan: 1,4. 24 July 2007; J. Avril, "Report exposes high water contamination". Sowetan, 3 August 2007; J. Avril, "Poisoned by mines". Sowetan, 20 August 2007; Anon., "SA 'Erin' widens toxic water fight. Water too dangerous for farming", The Citizen, 14 August 2007.

76 Compare the several letters and reports exchanged between environmental activist Ms Mariette Liefferink and the mining authorities as well as with the government and academics from tertiary institutions in M. Liefferink, 1988-2007. Private collection. See also SABC TV, Programme Carte Blanche, Genre Environment and conservation, Producer Carol Albertyn Christie, Presenter Devi Sankaree Govender, 12 August 2007; E. Tempelhoff, "Familie wil R53m van myn hê", Beeld, 24 Junie 2004; E. Tempelhoff, "Inwoners moet weet van giftige gebied", Beeld, 10 Augustus 2004; E. Tempelhoff, "Dam se water glo giftig", Beeld, 29 Januarie 2007; E. Tempelhoff, "Wonderfonteinspruit besoedeling is " $\mathrm{n}$ ramp wat duisende bedreig sê DA", Beeld, 20 Julie 2007; E. Tempelhoff, "Hoe het myne siek gemaak", Beeld, 30 Augustus 2007; E. Tempelhoff, "Myne misken menseregte, meen Bizos", Beeld, 11 September 2007; E. Tempelhoff, "Vrae oor stowwe op Rietvlei, verslag hoop op“, Beeld, 7 September 2007.

77 Compare the several letters and reports exchanged between environmental activist Ms Mariette Liefferink and the mining authorities as well as with the government and academics from tertiary institutions in M. Liefferink, 1988-2007. Private collection. See also the reference to the 1998 constitution earlier.

78 Compare Council for Geoscience Archive (CGA), Far West Rand Dolomitic Water Association (FWRDWA), Minutes, 1964-1967, Circular no 28/67, "Oberholzer irrigation canal: Pollution of water“, 29 Nov 1967; 
cannot be excused from an ethical point of view. ${ }^{79}$ Recent research also more frequently accentuates the effects of environmental pollution in the WRC on humans, animals and the biodiverse environment. ${ }^{80}$ In some way, it is a pity that the voices of concern in the 1960s were defended strategically and/or even shut with a kind of remuneration for losses. ${ }^{81}$ Therefore, after 55 years of operational gold and uranium mining activities in the Far West Rand, the negative outcomes for the public in the WRC include, but are not limited to

- dewatering;

- sinkhole and doline formations;

79 Compare N. Jacobs, Environment, power and injustice: A South African history (Cambridge, Cambridge University Press, 2003); A. Turton, H.J. Hattingh, G.A. Maree, D.J. Roux, M. Claassen \& W.F. Strydom (eds.), Governance as a trialogue: Government-Society-Science in transition (Berlin, Springer Verlag, 2007); RA Adler, M Claassen, L. Godfrey, A. Turton, "Water, mining and waste: an historical and economic perspective on conflict management in South Africa", The Economics of Peace and Security Journal, 2(2), 2007. Also compare E.S. van Eeden, "Ekonomiese ontwikkeling ...”, (Ch. 4-5; M. Liefferink, 1988-2007. Private collection, 2007.

80 E.J. Stoch, "Memorandum, [Krugersdorp game reserve: Animal mortality. V2]", 13 May 2005 [Draft report]; E.J. Stoch, "Some controversial health related issues in a karst environment (A historical perspective of the adversarial relationships between the role players in the Wonderfonteinspruit with specific reference to groundwater and pollution)", 1 Aug. 2006 [Draft notes to E.S. van Eeden]; R. Barthel, G. Deissmann, \& W. Leotwane, "Radiological impact assessment of mining activities in the Wonderfonteinspruit catchment area" (Environment Conference, Pilanesberg, NWU), 23-25 Jul. 2007; R. Barthel \& L. Funke, "Radiological risks of cattle watering at polluted surface water bodies in the Wonderfonteinspruit catchment area" (Environmin Conference, Pilanesberg, NWU), 23-25 Jul. 2007; Water Research Commission (WRC), H. Coetzee, F. Winde, P.W. Wade, Report No 1214/1/06, "An assessment of sources, pathways, mechanisms and risks of current and potential future pollution of water and sediments in gold-mining areas of the Wonderfontein Catchment", 2006; National Nuclear Regulator (NNR), "Technical report, Radiological impacts of the mining activities to the public in the Wonderfonteinspruit Catchment Area" [also known as the Brenk report], Jul. 2007; J.S. du Toit, "Background report on communities at risk within Mogale city local municipality affected by mining-related activities, with special reference to radiation \& toxicity", September 2007[Draft report].

81 National Archive of South Africa (NASA).NGR, Band 3, File 30. Pollution of waters, 1952, p. 1; NASA, SAB, GES, Band 2522, File 523/43. Pollution of water supplies, August-September, 1956; E.J. Stoch, ca 1960-1970. Private collection; E.S. Van Eeden, A.B. de Viliiers, H .Strydom \& E.J. Stoch, "Mines, peoples and sinkholes - An analysis of the Carletonville municipal area in South Africa as a case study regarding policies of secrecy", Historia, 47(1), May 2003; E.S. van Eeden, "Some human actions in the destruction and construction of culture and nature - the Merafong region as a case study", Journal for Transdisciplinary Research, 2(2), Dec. 2006; L.P. Graham, "The effect of acid mine drainage on the cave-dwelling amphipod, Sternophysinx filaris: A case study for the use of these amphipods as bioindicators", UJ (Hons. manuscript), 2007; R. Heyl, "The effects of mining effluent on the aquatic environment", UJ (Hons. manuscript), 2007. 
- elevated levels of radioactivity;

- radiological impacts: plants;

- radiological impacts: soil; 82

- pollution of shallow and deep groundwater such as dams, lakes and streams; $; 3$

- health impacts; ${ }^{84}$

- heavy metal contamination; ${ }^{85}$

- toxic and radioactive dust fallout;

- acid mine drainage; 86

- unfavourable soil conditions in the presence of pyretic tailings

- animal mortality ${ }^{87}$

The second example of an imbalance in the water quality is acid mine drainage (AMD). AMD is responsible for the most costly environmental and socio-economic impacts. It may still be a problem for many years after mines have closed. AMD is also associated with surface and groundwater pollution, the degradation of soil quality, harming aquatic sediments and fauna, and allowing heavy metals to seep into

82 Council for Geoscience, Report No. 2005-0106, H. Coetzee, J. Venter \& G. Ntsume, "Water Pollution Contamination of wetlands by Witwatersrand gold mines processes and the economic potential of gold in wetlands", 2005.

83 DWAF, J. Fourie and Associates, Report 16/1/7/C221/C/24, "Impact of the discharge of treated mine water, via the Tweelopies Spruit, on the receiving water body Crocodile River System, Mogale City, Gauteng Province”, 3 December 2006.

84 Compare FWRDWA, Minutes, 1964-1967, Circular no. 28/67, "Oberholzer irrigation canal: Pollution of water", 29 Nov 1967; NNR, "Technical report, Radiological impacts of the mining activities to the public in the Wonderfonteinspruit Catchment Area" [Brenk report], July 2007.

85 Compare WRC, Report No 1214/1/06, H. Coetzee, F. Winde, P.W. Wade, "An assessment of sources, pathways, mechanisms and risks of current and potential future pollution of water and sediments in gold-mining areas of the Wonderfontein Catchment", 2006.

86 Council for Scientific and Industrial Research (CSIR), Report CSIR/NRE/WR/ ER/2007/0097/C, P.J. Hobbs and J.E. Cobbing, ÒA hydrogeological assessment of acid mine drainage impacts in the West Rand basin, Gauteng ProvinceÓ, Aug. 2007.

87 Compare E.J. Stoch, "Memorandum, [Krugersdorp game reserve: Animal mortality. V2]", 13 May 2005 [Draft report]; R. Barthel \& L. Funke, "Radiological risks of cattle watering at polluted surface water bodies in the Wonderfonteinspruit catchment area" (Environmin Conference, Pilanesberg, NWU), 23-25 Jul. 2007 [Abstract]; J.S du Toit, "Background report on communities at risk within Mogale city local municipality affected by mining-related activities, with special reference to radiation \& toxicity", Sept 2007[Draft report]. 
the environment. Long-term exposure to AMD-polluted drinking water may, amongst others, lead to increased rates of cancer and skin infections. The Wonderfontein Spruit valley is densely populated because of its agricultural value and presence of gold mines. The majority of the inhabitants live in informal settlements, using contaminated ground- and stream water for personal hygiene and drinking. ${ }^{88}$ With above-average infection rates of HIV/AIDS and chronic and acute malnutrition, this subpopulation is particularly vulnerable to additional stress of the immune system by contaminants such as uranium. ${ }^{89}$

After continuous talks and complaints by local action groups, a forum to include all role players was established. In the WFC area, the Wonderfontein Action Group (WAG) was formed by Gold Fields on 5 July 2006 to consolidate all stakeholders as affected/"injured" and interested parties with a key focus on finding solutions that satisfy all. Not even Gold Field's appointment by an independent facilitator, Bigen Africa, could reach expectations because the role of Gold Fields as a leading polluter, now in a leading reconciliation role, was not accepted by the injured parties among the role players. ${ }^{90}$ As mentioned earlier, since 2007 the DWAF has taken the lead to establish committees and groups for the Wonderfontein Spruit Catchment area with the intention to find solutions to eventually progress actively

88 Compare J.F. Enslin \& J.P. Kriel, "Some results obtained from a hydrological study of a dolomite catchment area in the Transvaal" (Proceedings of the Specialists' Conference on Hydrology, Yaounde, Camerouns, CCTA, London, 14), 1959; J.F. Enslin \& J.P. Kriel, "The assessment and possible future uses of the dolomitic groundwater resources of the Far West Rand, Transvaal, South Africa" (Proceedings of the International Conference on Water for Peace, Washington, Publ. 2), 1967; J.F. Enslin, R.J. Kleywegt, J.H.T. Beukes, J.F. Gordon-Welsh, "Artificial recharge of dolomitic groundwater compartments in the Far West Rand gold fields of South Africa" (Proceedings of the International Symposium on Land Subsidence, Anaheim, California), 1976; J.F. Wolmarans \& F.H. Guise-Brown, "The water hazard in deep gold mining of the Far West Rand - South Africa (Symposium on Water in Mining, Siamos, Granada, Spain), 1978; O. Pollman; L. van Rensburg, F. Wilson, "Optimising the rehabilitation of polluted mine tailings and water by SupaZorb", Abstract, ca. 2006-2007; CJU Swart, AR James, R.J. Kleyweg \& E.J. Stoch, "The future of the dolomitic springs after mine closure on the Far West Rand, Gauteng, RSA", Environmental Geology, 44, 2003, pp.751-770.

89 Compare R.A. Adler, M. Claassen, L. Godfrey \& A. Turton, "Water, mining and waste: an historical and economic perspective on conflict management in South Africa", The Economics of Peace and Security Journal, 2(2), 2007; A. Turton, E-mail (to multiple recipients), "Mine water and strategic focus points", 16 Apr. 2007; F. Winde, "Challenges for sustainable water use in dolomitic mining regions of South Africa - a case study of uranium pollution. Part 1: Sources and pathways", [Draft publication], ca 2007.

90 Compare the information obtained through e-mail: W. Pepler (Bigenafrica, Pretoria)/E.S. van Eeden (Researcher), 22 October 2007. 
towards a practical remediation process.

By 2007, some gold mining companies in the Wonderfontein Spruit area started focussing on developing and refining their environmental management programme reports. While engagement started out as efforts by individual companies, efforts have been made to involve all gold-mining companies. To this end, the Mining Interest Group has been established as a substructure of the Wonderfontein/ Loopspruit Forum, through which mining companies can act in a consolidated manner in addressing catchment management issues.

Individual gold mining companies in the Wonderfontein Spruit area are using the Global Reporting Initiative (GRI) guidelines in reporting on their sustainable development performance. The purpose of the guidelines is to provide a common framework for reporting to assist organisations in meeting their non-financial reporting requirements, or for reporting on the economic, environmental and social dimensions of their activities. However, the use of these guidelines is voluntary. Some mines have also applied for or obtained ISO 14001 and 19011 accreditation. ISO 14001 (SANS 14001) is the flagship standard of the ISO (International Organisation for Standardisation) series and is widely known. ISO 19011 (SANS 19011) is the standard dealing with the auditing of both environmental and quality management systems and provides guidance on principles of auditing, managing audit programmes, conducting audits, and auditor competence. Gold Fields, in addition, has recently committed itself to the Global Compact and the Sustainable Development Principles of the International Council on Minerals and Metals (ICMM), as well as the implementation of the Cyanide Code. However, NGOs perceive remediation and mitigation measures as ethical efforts to correct the inadequacies of the past still to be reactive rather than proactive. ${ }^{91}$

In recent years, some gold mining companies also became more environmentally responsive, by closing research and other partnerships with statutory bodies (such as the CSIR and the Council for Geoscience), authorities (such as the DWAF), NGOs (such as the Wildlife and Environmental Society of South Africa WESSA), the IUCN and the Legal Resource Centre. To ensure a systematic and credible process of stakeholder engagement, Gold Fields has even implemented the AA1000 Stakeholder Engagement Standard of Accountability (SESA) in all its operations worldwide. ${ }^{92}$

91 Interview Marius Keet (DWAF)/E.S. van Eeden, 9 May 2008; Compare E.S. van Eeden, 2006-2007. Private collection; M. Liefferink, 1988-2007. E.S. van Eeden, Private collection (Response by Gold Fields to questions posed regarding recent development for writing this article), August 2007.

92 Private collection; M. Liefferink, 1988-2007. E.S. van Eeden, Private collection (Response by Gold Fields to questions posed regarding recent development for writing this article), August 2007. 


\section{Conclusion}

The major scope for discussion was to exchange ideas on the environmental ethics of the day as mainly reflected from a general post-modern ethical perspective. Amongst others, corporate crime that resulted from disregard of the ethical basis of the day. Although voices of concern in the WRC featured prominently through knowledge on several podiums and in numerous meetings, no extraordinary ethical approach towards this environment could be traced.

With specific reference to the WFC area and role players involved in the area through decades, the discussion indicated that norms and values regarding the environment and man's position in the environment are determined by how the government of any given period manages the environment. Ethics through knowledge do not necessarily feature prominently if the dominant motivation for environmental exploitation is an economic "goldmine", so to speak.

In the case of the WFC, an environmental policy analysis will reflect the classic choice between environmental protection and economic development. Gold mining and uranium activities in the WFC area in 1988 peaked at a contribution of $18 \%$ of the total gold mining production in South Africa. This even progressed in the years that followed. Many authorities under Government supervision for years operated in the area under a legal mandate with the environment only as an "object" to be explored with little means to be approached in reasonable ethical ways.

For Government to fulfil its obligations in terms of responsible environmental management, it must co-ordinate all the organs of State at all levels to ensure responsible environmental stewardship. Regrettably, the South African Government's environmental regulation of the Wonderfontein Spruit is perceived as being fragmented, diverse, uncoordinated and administered by underresourced, ill-informed (historical amnesia) and too many different government departments with far too many different voices singing their own solo on environmental heritage. The current environmental agenda will be decelerated by this politicking, collusion between Government and the gold mining corporations, injured role players and environmental activists. If unchecked, it may result in an increased threat to the Wonderfontein Spruit Catchment and its inhabitants, and the status quo cannot even be efficiently measured on the several ethically based democratic values of the country's constitution.

Lastly, the ethical strength of knowledge concerning the Wonderfontein Spruit Catchment environment - as overwhelmingly developed by experts in the natural sciences - highlighted the way in which authorities and institutions with power influenced the validity and the availability of findings. In this sense, the general 
saying by ethical experts that "knowledge is power" appears to be a sine qua non. Although the empowered authorities were unable to remedy certain past actions between the forties and sixties when key research findings on the Wonderfontein Spruit Catchment environment indeed were available, all findings from the seventies were equally underplayed or ignored. Government deliberately gave priority to the contribution of gold mining to economic growth, at the expense of the environment and people's well-being. Currently, the WSC is sometimes referred to as the toxic tsunami. The injured public voiced its concern by saying, "It is unethical to use tax payers' money to fund numerous research reports and then follow a path of intellectual amnesia". 93

With this enormous past baggage, it is especially up to the ANC government structures to pull up their socks and ensure that newly established groups and committees indeed can live up to the ethical expectations that the recently developed South African Constitution offers, ${ }^{94}$ and not to repeat the past in which the gold mines played the tune to which all danced. NGOs. scientists and scientific institutions still have to voice their concerns and knowledge through the ethically based constitutional structures to assist in positively working towards creating a sustainable environment in the Wonderfontein Spruit Catchment. The key for success or an improved environmental and human status lies in the multi-diverse and multi-disciplinary cooperation of people with knowledge and a concern to restore, support and strive towards righteousness to the environment and human beings that live in it.

93 Compare E. Tempelhoff \& E.S. van Eeden, Joint Paper on Government and the WRC, IWHA Conference, Drakensberg, 20-24 April 2008.

94 Interview Marius Keet (DWAF)/E.S. van Eeden, 9 May 2008. 